\title{
Drama HRABAL und der Mann am Fenster v kontextu tvorby Bernharda Setzweina
}

\section{Drama HRABAL und der Mann am Fenster in the Context of Bernhard Setzwein's Heritage}

Jindra Dubová

\begin{abstract}
Abstrakt
Příspěvek si klade za cíl představit hru HRABAL und der Mann am Fenster [Hrabal a muž u okna] východobavorského autora Bernharda Setzweina v kontextu jeho tvorby. Pozornost bude věnována Setzweinově tvorbě nejdřive prozaické a následně dramatické, dále vývoji českých námětů v autorových textech. Studie přibliží propojenost konkrétního motivu oběti a špicla v románovém a dramatickém ztvárnění. Následně bude představen literární styl autora a na základě konkrétních př́kladů z dramatu Hrabal a muž u okna poukážeme na integritu individuálního stylu autora jak v tvorbě prozaické, tak dramatické.
\end{abstract}

\section{Klíčová slova}

německé divadlo, divadelní a prozaická tvorba Bernharda Setzweina, HRABAL und der Mann am Fenster, Hrabal a muž u okna, Bernhard Setzwein, obět’ a špicl

\begin{abstract}
The article aims to introduce the play HRABAL und der Mann am Fenster [Hrabal and the Man at the Window] by the East-Bavarian author Bernhard Setwein in the context of his literary heritage. Setzwein's prosaic and, subsequently, dramatic work, as well as references to Czech issues in the texts of the author become the centre of present discussion. The article focuses on the topic of the interconnectedness of the victim and informer in prosaic and dramatic interpretation. Furthermore, the article focuses on the literary style of the author and, based on the examples from the play Hrabal and the Man at the Window, the integrity of the individual style of the author in his prosaic and dramatic work.
\end{abstract}

\section{Key words}

German Theatre, dramatic and prose work od Bernhard Setzwein, HRABAL und der Mann am Fenster, Hrabal a muž u okna, Bernhard Setzwein, victim and informer 


\section{Bernhard Setzwein - prozaická tvorba}

Bernhard Setzwein se narodil roku 1960 v Mnichově. Zde vystudoval germanistiku a folkloristiku. Dnes žije ve Waldmünchenu (Bavorsko) na česko-bavorské hranici. Působí jako spisovatel na volné noze a mimo svou literární činnost spolupracuje již mnoho let s Bavorským rozhlasem [Bayerischer Rundfunk], pro který píše reportáže z oblasti kultury a cestování. Za svou tvorbu získal řadu významných ocenění, např. cenu Friedricha-Baura Bavorské akademie krásných umění.

Jeho literární začátky jsou spojené především s poezií, kterou začal psát v osmdesátých letech. Básně jsou psány částečně v bavorském nářečí a vyjadřují touhu po nalezení vlastní identity, mísí se zde pocity osamělosti, ale i naděje (srovnej SETZWEIN 1978). Pro svou románovou prvotinu Brandwunden [Popáleniny] (SETZWEIN 1981) volí autor prostředí rodného Mnichova, konkrétně čtvrti Sendling. Ta je mu dobře známá, jelikož zde vyrůstal jeho otec a jeho dědeček v této čtvrti provozoval hostinec. V románu spisovatel otevírá otázky novodobého fašismu, spojeného se systematickou denunciací a terorem člověka, který zastává odlišný názor. Změna témat přichází postupně v souvislosti s autorovým přestěhováním v roce 1991 do bavorského města Waldmünchen na bavorsko-české hranici. Události, které ovlivňují tento region v době po pádu železné opony, si v Setzweinových textech nacházejí své místo. V letech po přestěhování se do Waldmünchenu Setzwein píše nadále knihy, které se svým obsahem vztahují k Mnichovu a přilehlému regionu, např. jeho kulturně-historický průvodce okolím řeky Isary (SETZWEIN 1993a) nebo román Das Buch der sieben Gerechten [Kniha sedmi spravedlivých] (SETZWEIN 1999). Objevují se ale především krátké literární útvary, které prozrazují rozšíření témat. Přímý kontakt s českým prostředím ovlivňuje obsah Setzweinovy tvorby. Působení regionu ležícího na hranici mezi Čechami a Bavorskem se ukazuje např. ve sbírce textů Ein Fahneneid aufs Niemandsland. Literatur über Grenzen [Slib věrnosti vlajce zemi nikoho. Literatura o hranicích] (SETZWEIN 2001). Velká pozornost je věnována českým, ale také např. polským námětům. Setzweinova epická báseň OberländerEckeDaiser [Na rohu ulic Oberländer a Daiser] (SETZWEIN 1993b) je prvním větším literárním útvarem, ve kterém se část děje odehrává v Čechách. V roce 2003 vychází Setzweinův román Die grüne Jungfer [Zelená panna] (SETZWEIN 2003), který v sobě spojuje některé z námětů, které se doposud objevují jen v krátkých literárních textech orientovaných na Čechy. Román je součástí trilogie Aus der Mitte der Böhmischen Masse [Zprostředka Českého masivu], která obsahuje výše zmiňovaný román, dále romány Ein selstames Land [Podivná země] (SETZWEIN 2007a) a Der neue Ton [Nový tón] (SETZWEIN 2012). Tématem románu Die grüne Jungfer (SETZWEIN 2003) je ztvárnění historie české fiktivní příhraniční vesnice a prakticky středoevropských dějin 20. století a dále popis změn v české společnosti v období po sametové revoluci. Román je psán jako literární montáž, která je složena z několika časových rovin. Vyprávěný čas se pohybuje v rozpětí od 2. 6. 1865 do 14. 6. 1991. Hlavní osa děje je situována do jednoho jediného dne, a to 14. 6. 1991. Hlavní postavou je bývalý komunistický disident Vančura, který se svým jednáním snaží zkomplikovat prodej místního zámku německému podnikateli. Ten v něm zamýšlí zřídit velkochov slepic. V rámci Vančurova vyprávění 
probíhá druhá časová rovina románu, která průřezově tematizuje středoevropské dějiny 20. století. Dotýká se událostí spojených s druhou světovou válkou, následným odsunem sudetských Němců a v neposlední řadě s životem v komunistickém Československu, který je v románu ztvárněn velkou měrou na osudech postav bývalého disidenta Vančury a jeho špicla jménem Lovec. Ten je na Vančuru nasazen, aby zjistil, zda píše texty s protistátním obsahem.

Ve volném pokračování s názvem Ein seltsames Land (SETZWEIN 2007a) je hlavní postavou podomní prodejce vysavačů Lober. Jeho životní situace, nerozhodnost v osobních vztazích a život ve společnosti, která je orientována silně individualisticky a výkonnostně, ho přiměje $\mathrm{k}$ tomu, že se rozhodne opustit svůj denní stereotyp a vydává se z Bavorska do neznáma, směrem na východ. Tématem románu je jeho cesta střední Evropou. Zatímco Bavorsko je v rámci děje líčeno na základě přesných geografických údajů, Čechy jsou prezentovány jako poetický, skoro až surrealistický prostor, který koresponduje s vnitřní proměnou hlavního hrdiny.

Tyto dva romány se spojují v závěrečném dílu trilogie Der neue Ton (SETZWEIN 2012). Odehrává se v bezprostřední současnosti (viděno z románové perspektivy). Postavy z obou románů se v třetím díle objevují v nových konstelacích, setkávají se následně v rakouském Waldviertelu a poté se jejich cesty zase rozcházejí. Lober zde definitivně nachází svoji životní rovnováhu, Vančura připravuje expozici pro nově plánované „Muzeum historie Českého masivu“. V trilogii Aus der Mitte der Böhmischen Masse se autor v rámci literárních dějů pohybuje celkově ve středoevropském prostoru, i když akcentuje hlavně ten český. To se odráží právě ve zmiňovaném názvu trilogie, který v sobě zahrnuje geologické označení Český masiv. Tímto geologickým názvem je předurčen prostor, ve kterém se v trilogii $\mathrm{v}$ různých časových úrovních prolínají dějiny s prríběhy literárních figur. Tímto způsobem se snaží Setzwein zachytit bohatou plasticitu tohoto území, dotýká se mnoha významových rovin, které zčásti fungují jako izolované příběhy, ale zároveň přispívají ke ztvárnění tohoto prostoru.

Setzweinův doposud poslední román Der böhmische Samurai [Český samuraj] (SETZWEIN 2017) vypráví neobyčejný př́běh rodiny Coudenhove-Kalergi z první poloviny 20. století, který se z velké části odehrává v Poběžovicích na Šumavě.

Na vybraných prozaických dílech bylo ukázáno, že Setzwein paralelně pracuje jak na námětech z Německa, tak i z Čech, s celkovým přesahem do středoevropského prostoru. Za hlavní důvod, proč se Setzwein začal zabývat českou tematikou, je třeba považovat jeho přestěhování se do př́hraničního regionu. On sám dále uvádí, že jeho zájem o Česko byl ovlivněn i četbou české literatury, především děl Franze Kafky, Bohumila Hrabala či Pavla Kohouta (DUBOVÁ 2019).

\section{Vývoj témat v dramatické tvorbě}

Dramatické tvorbě se Bernhard Setzwein začíná věnovat v devadesátých letech. Jeho první drama Zucker. Ein Stück. Diabetische Farce in 4 Szenen [Cukr. Hra. Diabetická fraška o 4 scénách] (SETZWEIN 1997) se stejně jako jeho prozaická tvorba v této době obrací 
k Mnichovu. Protagonisty jsou dva diabetici, kteří spolu leží v nemocnici ve stejném pokoji, ale ke své nemoci přistupují zcela odlišně. Jeden z nich je tělnatý a svoje onemocnění nebere nijak vážně. Druhý pacient je starý muž, který nad svou nemoci přemýšlí a zaobírá se jí z mnoha úhlů pohledu. A právě skrz tyto postoje poukazuje Setzwein na paralelu s hitlerovským Mnichovem. Dramatik srovnává masové chování lidí s chováním diabetika, který záměrně nedodržuje lékaři doporučená pravidla.

I jeho další hra Watten Wagner Wichs (prem. 6. 2. 2004, Mnichov, Německo) se odehrává v metropoli nad Isarou a vrací se ke stejnému období historie tohoto města. V mikrokosmu jednoho mnichovského pokoje se odvíjí krátký příběh, který ukazuje mladého, nacismem zfanatizovaného muže, jehož chování je ovšem zcela nevyrovnané. Rozhovory u stolu, které se točí okolo každodenních věcí, jsou prosycené demagogií hitlerovského Německa. Tak jako předešlé zmíněné drama, i hra 3165 - Monolog eines Henkers [3165 - Monolog kata] (prem. 7. 12. 2007, Weiden, Německo) přibližuje historicky podložený příběh. Jeho hlavní postavou je poslední bavorský kat.

Setzwein si pro svou tvorbu vybírá jak motivy ze současnosti, tak i z minulosti: např. divadelní hra LOLA MONTEZ - die falsche Spanierin [LOLA MONTEZ - falešná Španělka] (prem. 29. 6. 2018, Vilseck, Německo). Ve středu zájmu se objevují postavy, které budí kontroverzi a odhalují různé postoje společnosti. Nejinak je tomu v př́ípadě hry Resl unser. Das Stück zum Film vom Fall des Konnersreuther Mysteriums [Resl naše. Hra o filmu k konnersreuthského tajemství] (prem. 14. 3. 2019, Weiden, Německo) o bavorské ženě Theres Neumann, u které se objevovala zjevná stigmata a pravidelně upadala do tranzu, ve kterém prožívala Ježíšovo utrpení.

Autorova doposud poslední divadelní hra Großmutter, das Viruserl und die Zukunft [Babička, malý vir a budoucnost] (prem. 16. 6. 2021, Mnichov, Německo) je určena pro loutkové divadlo. Je postavena na kontrastu tradičních postav loutkového divadla a současné tematiky pandemie v kombinaci s aktuálním textem celé hry. Autor k námětu přistupuje s ironií, vtipem, zároveň ale i vážností a kritickým nadhledem. Kromě toho se objevují dvě mluvící zviřata, ptačí dáma a netopýŕí muž. Právě tito zástupci zviřecí řĩse komentují svým sarkastickým způsobem lidské počínání v době, která je poznamenána celosvětovou pandemií. ${ }^{1}$

\section{Drama HRABAL und der Mann am Fenster}

Divadelní hra Bernharda Setzweina HRABAL und der Mann am Fenster [Hrabal a muž u okna] byla poprvé uvedena v Řezně (Německo) v režii Mii Constantinové (prem. 6. 6. 2015). Hra byla přeložena do češtiny Zuzanou Čtveráčkovou a nese titul Hrabal a muž u okna (SETZWEIN n.d.). Poprvé ji bylo možné zhlédnout v Praze ve formě scénického čtení dne 14. 3. 2019 ve Vršovickém divadle MANA. ${ }^{2}$ Hra vyšla i knižně v německém

1 Přehled téměř všech divadelních her Bernharda Setzweina viz www.bernhardsetzwein.de.

2 Obsazení: Dudek (v německém originále Dutky): Ondřej Vetchý, Hrabal: Arnošt Goldflam, Lenka: Veronika Svojtková, režie: Ondřej Zajíc. Dne 26. 5. 2021 byla tato hra uvedena v Městském divadle Brno (oficiální prem. 6. 11. 2021) v režii Stanislava Moši. Obsazení: Dudek: Jan Mazák, Hrabal: Viktor Skála, Lenka: Radka Coufalová. 
originále. V rámci této knihy (ECKER und ECKER 2015a) je uveden text divadelní hry HRABAL und der Mann am Fenster (SETZWEIN 2015b), ${ }^{3}$ následuje obsáhlý komentář k dramatu od editorů knihy, kde je objasněn především obsahový podtext spojený s postavou Bohumila Hrabala jako spisovatele. Druhou část knihy tvoří text bamberských poetologických přednášek Bernharda Setzweina (SETZWEIN 2015a). ${ }^{4}$ Knihu uzavírají novinové články a interview vztahující se k uvedení této hry v Řezně. Zatímco v tvorbě Bernharda Setzweina najdeme již několik románů s českou tematikou, u divadelních her tomu tak není. Hrabal a muž u okna je mezi jeho dramaty jediná divadelní hra, která je zasazena do českého prostředí. Sepsání této hry následuje z chronologického hlediska po dokončení trilogie Aus der Mitte der Böhmischen Masse. Setzwein do ní promítá několik motivů z uvedené trilogie, přičemž motiv oběti a špicla se stává nosným pro celé drama. Ukážeme zde propojenost prozaické a literární tvorby Bernharda Setzweina na př́kladu tohoto dramatu a uvedeme shodné i rozdílné intence v pojednání motivu oběti a špicla.

HRABAL und der Mann am Fenster (SETZWEIN 2015b) je hra se třemi postavami, o šesti scénách a její vyprávěný čas je určen několika hodinami v létě roku 1997. Místem je chatová oblast v Kersku ve Středočeském kraji. Muž, jehož jméno je Dutky, stojí s dalekohledem u okna v polorozpadlé boudě na nářadí plné harampádí a pozoruje ovocnou zahradu s chatou, která patří českému spisovateli Bohumilu Hrabalovi. Takto je v dramatikových scénických poznámkách uvedeno první dějství. S pedantickou přesností zaznamenává Dutky údaje o svém objektu pozorování. Zprávy potom předává Státní bezpečnosti, konkrétně je ve styku s majorem Lánským. Bohumila Hrabala ale již dlouho neviděl. Dutky neustále volá svou ženu Annu, která nepřichází. Anna má za úkol jeho zprávy vždy přepsat na stroji a poté odnést do krajského města.

Ve druhé scéně přichází mladá žena jménem Lenka. Zajímá se o Dutkyho zprávy, chtěla by je využít v rámci připravovaného muzea Bohumila Hrabala, které má vzniknout z jeho chaty. Dutky si původně myslí, že je od Státní bezpečnosti, během rozhovoru ale zjistí, že Lenka je z turistické kanceláře. Ta mu také sděluje, že Bohumil Hrabal je po smrti. Zároveň se ukazuje, že i Dutkyho žena Anna zemřela a že došlo ke změně politických poměrů. Zprávy, které původně Anna vozila do krajského města, předávala po revoluci své sousedce, která je uchovávala a od které je Lenka následně získala.

Ve třetí scéně Dutky, mírně ovíněný svým rybízovým vínem, vypráví Lence o Bohumilu Hrabalovi. Ta ho při tom natáčí na kameru a nabízí mu místo průvodce v Hrabalově

$3 \quad$ V textu článku jsou používané odkazy jak na německý originál dramatu (SETZWEIN 2015b), tak na jeho český překlad (SETZWEIN n.d.).

4 Bamberské poetologické přednášky je soubor autopoetologických a esejisticky zaměřených textů Bernharda Setzweina, který nese název „,Herr Schriftsteller, vergessen Sie die Mütze nicht!“ Mitteleuropa und der gar nicht kalte Osten (SETZWEIN 2015a). Autor se zde vyjadřuje ke svému dílu a způsobu psaní především s důrazem na jeho román Die grüne Jungfer. Přednášky vznikly v roce 2004, kdy Bernhard Setzwein působil na Otto-Friedrich-Universität v Bambergu v rámci renomovaného programu „Bamberger Poetikprofessur“. 
muzeu. Ve svém povídání pokračuje Dutky i ve čtvrté scéně. Svým vyprávěním o Hrabalovi dochází postupně k sebereflexi, vyjadřuje svá přání, ale i následnou frustraci.

Pátá scéna je vyvrcholením celé hry. Hrabal se objevuje jako postava z jiného světa a je rozehrán dialog mezi obětí a jejím špiclem, kde dochází k jakési formě usmíření obou. Děje se tak formou vzájemného rozhovoru, kde se Dutky pod hrabalovským vedením mění v surrealistického umělce. V konečné šesté scéně se stává Dutky průvodcem v nově zř́izeném muzeu Bohumila Hrabala.

\section{Opozitní pár: špicl - obět' v prozaické a dramatické tvorbě Bernharda Setzweina}

Setzwein považuje motiv oběti a špicla za univerzální. Na danou konstelaci pohlíží autor i v širším slova smyslu jako na pozorujícího a pozorovaného, nevnímá ji jen v souvislosti s totalitním režimem. Nabízí srovnání se svou výchovou v katolické rodině, kdy se jako malý chlapec neustále cítil pod dohledem jisté síly, tedy neustále pozorován (viz SETZWEIN 2021). Zde můžeme hledat jeden z důvodů, proč se Setzwein k tomuto motivu opakovaně vrací.

Špicla a jeho obět ve formě odpůrce režimu v podobě bývalého disidenta použil Setzwein poprvé ve svém románu Die grüne Jungfer. Konstelaci donašeč a jeho obět́ zpracovává následně i ve své dramatické tvorbě v Hrabalovi a muži u okna. Pro obě díla je společné, že se děj odehrává v devadesátých letech v Čechách, přičemž je akcentována reflexe do doby komunistického Československa.

V románu Die grüne Jungfer je na základě personálního vyprávění, které je u postavy špeha jménem Lovec použito velmi často, polopřímé řeči i vnitřního monologu, čtenáři poskytnut detailní vhled do jeho myšlenek a pocitů. Také u postavy Dutkyho jsou podrobně prezentovány myšlenky této postavy, a to formou jeho dlouhých monologů.

U obou dvou postav využívá autor obdobných prostředků, aby dokumentoval, jak absurdní a nicotná jejich činnost v důsledku je. Výpovědní hodnota zpráv, které Dutky zapisuje, je bezvýznamná. „Devět třicetdva / přibližně pětadvacet kousků koček / se potuluje v okolí a kolem chatky / Jasné znamení / že se (myšleno Hrabal, poznámka autorky) zase objeví“ (SETZWEIN n.d.). Ve svém od okolí izolovaném světě Dutky neví, že Hrabal zemřel, a stále očekává jeho příchod. Neuvědomuje si ani smrt své ženy. Nezaznamenává, že se úplně změnily politické poměry, existuje ve svém vlastním světě. Neví, proč je Hrabal nebezpečný, nerozumí tomu, ale otrocky zapisuje jakékoliv dění (SETZWEIN 2015b: 22). Hrabalovy styky s cizinou mu paradoxně zůstávají neznámou, jak se ukazuje v dialogu s Lenkou (SETZWEIN 2015b: 31). Právě až její přítomnost přeruší Dutkyho pseudoexistenci. Ona mu poskytne údaje o současném stavu věcí, a protože on o Hrabalovi ví nejvíce, nabízí mu místo průvodce v muzeu věnovaném českému spisovateli.

Také u Lovce jsou zprávy, které se týkají pozorovaní Vančury a jsou určeny pro StB, obsahově nerelevantní, jak je vidět na rozhovoru s jeho ženou, která po jejich přečtení reaguje následovně: „Nemůžu si pomoct: teda nic moc, tohleto, řekla bych. [...] / Chceš 
vážně tvrdit, žes po celejch těch dvacet let psal zprávy, jako je tahle?“ (SETZWEIN 2007b: 81). Stejně jako v Hrabalovi a muži u okna ani v Die grüne Jungfer nejsou agenti schopni zachytit podstatné informace. Dutky netuší, že Hrabal cestoval po Evropě (viz výše), a ani Lovec nebyl po celá léta schopen zjistit, zda Vančura pracuje na nějakém tajném textu či vyvíjí protistátní činnost. Odpověd' na to, zda tento bývalý disident skutečně něco psal a tvořil za doby, kdy ho Lovec pozoroval, je plně zodpovězena až ve třetím díle trilogie Der neue Ton (SETZWEIN 2012). Dozvídáme se, že Vančura byl literárně činný, nepsal však knihu s protistátním obsahem, ale pracoval na rozsáhlém díle s námětem dějin lidstva.

V samotném názvu hry Hrabal a muž u okna kontrastuje uvedení konkrétního jména vztahujícího se k spisovateli Bohumilu Hrabalovi s druhou postavou, která je záměrně vyjádřena obecným podstatným jménem „,muž“, a ne jménem postavy. Nejde tak o její přesnou identitu, ale o její charakter, který je přenosný (ECKER und ECKER 2015b: 87). Jedná se o někoho, kdo v podstatě jakémukoliv režimu slepě podlehl, svou odpovědnost za své činy přesouvá na jiné a své vnitřní alibi zaštituje tím, že své konání podkládá tvrzením druhých. Ve hře je tento fakt dokumentován neustálým odkazováním se Dutkyho na názory Lánského, který je jeho kontaktní osobou u StB. Uved’me zde jen některé příklady: „Pcha, Rusáci, / od těch se pořád máme co učit / To ř́ká Lánský taky [...]“ (SETZWEIN n.d.). . ,Jednou tady i byl / Lánský / Osobně všechno zkontroloval / Ideální pozorovací stanoviště / řekl [...]“" (SETZWEIN n.d.).

K motivu donašeče a jeho oběti se Setzwein ve své tvorbě opakovaně vrací, využívá obdobných prostředků k ztvárnění těchto postav, rozvijí je ale v rozličných intencích. Již v prvních kapitolách románu Die grüne Jungfer se dozvídáme, že život Lovce v době po sametové revoluci ztratil smysl, když se psaní udavačských zpráv, které informovaly o každodenní činnosti Vančury, staly nežádoucí (SETZWEIN 2003: 28). Také Dutky, ve chvíli, kdy mu Lenka osvětlí pravý stav skutečnosti, ztrácí smysl života. Oba shodně pocitují své oběti jako vítěze. Zatímco se ale Lovec v Die grüne Jungfer sám stává obětí své vlastní nenávisti k osobě, kterou sleduje, u Dutkyho dochází k jistému smíření s danou situací a přijmutí nové role (ECKER und ECKER 2015c: 135). Vyznění osoby Dutkyho společně se závěrem celého díla je možno shrnout do několika rovin:

Paradox celkového vyznění hry působí groteskně [...], kdy se z bývalého špicla stane zaměstnancem muzea, kde bude Dutky své oběti, kterou po celá léta s pocity nenávisti pronásledoval, tak říkajíc vzdávat hold jako výjimečný služebník chrámu. [...] Hrabal bude mít nakonec své muzeum, protože si od toho turistická kancelář slibuje navýšení svých obchodů, a ne proto, aby byl oceněn jeho politický vzdor nebo kvalita jeho uměleckého díla. (ECKER und ECKER 2015c: 133$)^{6}$

5 V německém originále se jedná o následující znění: „Dutky: Tja die Sowjets / von denen kann man eben noch was lernen / Das sagt auch der Lánský [...]" (SETZWEIN 2015b: 14). Ecker upozorňuje i na ironický aspekt, který je spojen s touto formulací. V NDR bylo německo-ruské přátelství propagováno právě větou: „Von der Sowjetunion lernen, heißt siegen lernen (Učit se od Sovětského svazu, znamená učit se vítězit)“ (ECKER und ECKER 2015b: 91).

6 Není-li uvedeno jinak, jsou veškeré překlady cizojazyčných citací pracovním překladem autorky studie. 
Ironie spočívá v tom, že v muzeu Hrabala bude pracovat jeho bývalý špicl a toto muzeum zřizují ziskuchtiví podnikavci. Nejde o Hrabalovy myšlenky a skutečné hodnoty, ale o lákadlo pro turisty.

\section{Integrita literárního stylu autora v prozaické a dramatické tvorbě}

Literární styl Bernharda Setzweina je charakterizován několika typickými rysy, které se objevují jak v prozaické, tak dramatické tvorbě. V Setzweinových dílech s českou tematikou se silně projevuje autorovo vnímání české literatury. Setzwein si na základě své četby českých autorů všímá společných znaků jejich děl. K nim patří scény popisující popíjení alkoholu, především piva, děj bývá zasazen do období léta, texty působí nadčasově, melancholicky (SETZWEIN 2015a: 186, 210). Z tohoto důvodu se i román Die grüne Jungfer odehrává v červnu, hra Hrabal a muž u okna je zasazena také do léta.

Jedním ze základních rysů Setzweinovy tvorby je intertextualita. Proces psaní znamená pro autora mimo jiné osobní dialog s knihami, které již jednou přečetl, mluví o interakce mezi literárními díly (SETZWEIN 2021). S takto získanými myšlenkami pracuje dále, polemizuje s nimi a zakomponovává je do svých dalších textů. Někdy se jedná o krátké slovní spojení, jindy o volně inspirované vyjádření. Pro čtenáře či diváka jsou tato spojení často obtížně identifikovatelná, proto se zde pohybujeme na samé hranici intertextuality, nebot nemůžeme předpokládat jasný odkazový charakter k výchozímu textu (BÖHN 2007: 207). Autor nabízí čtenáři jistý druh intelektuální hry, která zprostředkovává další rovinu pochopení textu. Nejinak je tomu u dramatu Hrabal a muž u okna. Intertextualita zde představuje metarovinu hry, která je zde spojena především s dílem Bohumila Hrabala. Uved'me například ve hře obsažený skoro doslovný citát z Hrabalova autobiografického textu Kdo jsem (HRABAL 1989): „Vždycky jsem si přál měnit sám sebe / toho / kterého jsem měl na dosah ruky / sebe sama“ (SETZWEIN n.d.). Dramatik na základě odkazu na autobiografický text Hrabala deklaruje nesmyslnost Dutkyho počínání. Dutky neví, proč je Hrabal nebezpečný, nechápe jeho myšlenky, jak je v dramatu konkrétně deklarováno například na tomto citátu, ale pedanticky si zapisuje vše, co je schopen o Hrabalovi zjistit.

Intertextualita obsažená v tomto dramatu a věci týkající se českých reálií nemusejí být především pro německého čtenáře/diváka vždy srozumitelné. Setzwein se je snaží zprostředkovat tak, aby mohly v díle existovat samy o sobě a recipient nebyl nutně vázán na znalost českého prostředí. O tom svědčí i fakt, že hra byla v německé prostředí pozitivně přijata (viz BOCKHOLT 2015).

Setzwein při své tvorbě rád volí jména figur, která podtrhují charakteristiku a typizaci postav (mluvící jména). V textech s českou tematikou se dále vyskytují jména, která jsou vázána na konkrétní prostředí (Česko), jsou ale obvykle inspirována známými osobnostmi. V románu Die grüne Jungfer je to hlavní postava Vančury, jehož př́ímení se vztahuje k českému spisovateli Vladislavu Vančurovi. Také časté intertextuální odkazy na texty tohoto spisovatele $\mathrm{v}$ zde uvedeném románu svědčí o Setzweinově oblibě jeho 
díla. Ztvárnění literární postavy Vančury v Die grüne Jungfer ale nikterak nekoresponduje s životem a dílem tohoto českého literáta, odpovídá typu československého disidenta v období po pražském jaru. Postava vykazuje zároveň biografické podobnosti s životem Bohumila Hrabala (ECKER und ECKER 2015b: 88-89). Stejně tak i ženská postava Bohumily v tomto románu skrývá ve svém jménu odkaz na Bohumila Hrabala. V Hrabalovi a muži u okna vybírá Setzwein relativně frekventované ženské jméno Lenka, které na základě svého původu v sobě skrývá jistý potenciál svůdnosti (ECKER und ECKER 2015b: 89), který tato ženská postava využívá i při jednání se starým mužem (Dutkym), aby ho přiměla vyprávět. U Dutkyho i Lovce, tedy jak v dramatickém, tak prozaickém ztvárnění donašečů, používá spisovatel mluvící jména s významem blízkým estébáckým praktikám. V Die grüne Jungfer se jedná o Lovce, který číhá na svou kořist, v divadelní hře je to Dutky, jehož jméno vychází z českého slova „,důtky“ jako nástroje trestání. Pro český překlad dramatu zvolila Zuzana Čtveráčková pro tuto postavu jméno Dudek, které je jménu Dutky foneticky podobné. Př́ijmení Dutky nezní česky a bez použití diakritiky nedochází ani k zamýšlené asociaci se slovem „důtky“.

Setzweinův smysl pro surrealistická ztvárnění, které se v jeho dílech projevují často ve formě snů či halucinací postav, se v tomto dramatu promítá do pojetí Hrabalovy postavy. Tento český spisovatel zde není ztvárněn jako člověk z tohoto světa, ale nabízí se více možností, jak interpretovat tuto postavu. Je možné, že se jedná o Hrabalova ducha, Dutkyho snovou představu či projekci Dutkyho podvědomí. Při setkání Hrabala a Dutkyho v páté scéně hovoří Hrabal o momentech svého života. Zde Setzwein pracuje s reálnými fakty ze života českého umělce, jak to můžeme vidět i u jiných předobrazů postav v Setzweinových dílech. Pro tento dialog se dané údaje stávají jen jakýmsi odrazovým můstkem, na jejichž základě Hrabal tvoří v podstatě další umělecké dílo. I tímto způsobem Setzwein vzdává Hrabalovi hold.7 Způsob, jakým Hrabal hovoří, je sám o sobě pln energie, mluví o různých způsobech tvorby, jeho ideálech umění. Nejen tato scéna, ale celý Setzweinův text dramatu se nese v duchu surrealistické Hrabalovy poetiky. Text plyne volně, interpunkce je používána zřídka, což bylo zachováno i v českém překladu.

Pátá scéna je zakončena explozí rybízového vína. Svým významem je tento obraz srovnatelný s bouří, kterou končí román Die grüne Jungfer (viz SETZWEIN 2003: 278). Je to exploze, která signalizuje dokončení změny. Pokud bychom o postavě Hrabala uvažovali jako o snové představě, odpovídá toto ztvárnění surrealistické teorii, kdy je sen chápán jako součást lidské existence, která ovlivňuje naše činy. V této snové představě, či při této podvědomé projekci, překonává Dutky svůj vnitřní odpor ke své oběti a je připraven prrijmout svoji novou společenskou roli.

Setzwein ireálná setkávání rád využívá i ve své próze. Jako př́klad uved’me setkání Setzweina a císaře Rudolfa II. V krátké povídce „Wo bleibt das Spalier fähnchenschwingender Schulkinder?" [Kde zůstal špalír dětí s mávátky?] (SETZWEIN 2009: 18) z knihy Zu Fuß auf der Goldenen Straße [Pěšky po Zlaté stezce] (BRANDL et al. 2009). Tento

7 Ze svého obdivu k Hrabalově tvorbě se Setzwein obšírně vyznává již v bamberských poetologických přednáškách (SETZWEIN 2015: 186, 208), kde vyzdvihuje především Hrabalovo objevování nevšedního v prostém, humor nebo nadčasovost jeho textů. 
cestopisný deník zachycuje cestu tř́i autorů, kteří se v roce 2006 rozhodli projít Zlatou stezku z Plzně do Ambergu. Postava císaře Rudolfa II. funguje v uvedené povídce Bernharda Setzweina jako fiktivní průvodce česko-bavorským př́ihraničím, odhaluje jeho historii a zároveň i své myšlenky a představy. Obdobné setkání zažije i hlavní postava druhého dílu zmiňované trilogie v knize Ein seltsames Land Lober. Ten jako spolujezdec usíná v autě, které směřuje přes Čechy dále na východ. Ve snu $\mathrm{k}$ němu přistupuje do auta postarší muž, kterého můžeme identifikovat jako Adalberta Stiftera. Ten ho provází různými místy, která jsou líčena pomocí skurilních obrazů. Muž s Lobrem ve snu letí ke kostnici, která je v knize velmi detailně popsána. Ačkoliv konkrétní místo jmenovitě uvedeno není, můžeme se domnívat, že se jedná o kostnici v Kutné Hoře. Poté, co se Lober probudí, zjistí od své spolujezdkyně, že místy, o kterých snil, skutečně autem projížděli. Setzwein tedy opět využívá prostor snu a snové představy pro zprostředkování jiných perspektiv, ve kterých se ale nevyhýbá ani konkrétním údajům a faktům z reálného světa (SETZWEIN 2007a: 192).

\section{Závěr}

České náměty se začínají objevovat v díle bavorského spisovatele Bernharda Setzweina v souvislosti s jeho přestěhováním se do blízkosti česko-bavorské hranice. Nejprve se jedná o krátké literární texty, později romány. Hrabal a muž u okna je doposud jediné drama v díle Bernharda Setzweina s obsahovou vazbou na Čechy. Autor v ní rozvíjí motiv špicla a oběti, které poprvé zpracoval ve svém románu Die grüne Jungfer. Ukázali jsme podobnosti ve ztvárnění postavy donašeče jak v románovém, tak v dramatickém pojetí. Zatímco v Die grüne Jungfer se špicl stává obětí své vlastní léčky, v dramatu dělá Setzwein tak trochu $\mathrm{v}$ hrabalovském stylu ze špicla průvodce $\mathrm{v}$ muzeu (ECKER und ECKER 2015c: 135). Ironií ovšem zůstává účel zřízení tohoto muzea, tedy fakt, že se nejedná prvořadě o důstojnou vzpomínku na českého spisovatele, ale o slibnou finanční investici.

Setzwein vyzdvihuje osobnost Bohumila Hrabala ve své hře neotřelým způsobem. Nechá ho znovu ožít $\mathrm{v}$ podobě jakési snové představy a nechá ho hlavně znovu tvořit. V kontrastu s momenty z Hrabalova života ukazuje způsob, jakým se Hrabal snažil díky své tvorbě společně s jeho přáteli umělci čelit době totalitního režimu. K Bohumilu Hrabalovi jako autorovi se bavorský dramatik přibližuje i zvolenými uměleckými postupy. Jedná se především o surrealistická ztvárnění a intertextualitu, která je pro oba autory př́značná. Jak jsme ukázali, Setzwein nevolí tyto literární postupy pouze v souvislosti se zde pojednávaným dramatem, ale jsou pro jeho literární texty typické. 


\section{Bibliografie}

BOCKHOLT, Claudia. 2015. Wie man ein Regime in Trümmer lacht. In Hans-Peter Ecker und Kirsta Viola Ecker (Hrsg.). Bernhard Setzwein: HRABAL und der Mann am Fenster. Bamberg: University of Bamberg Press, 2015: 242-243.

BÖHN, Andreas. 2007. Intertextualitätsanalyse. In Thomas Anz (Hrsg.). Handbuch Literaturwissenschaft. Methoden und Theorien. Stuttgart: J.B. Metzler'sche Verlagsbuchhandlung und Carl Ernst Poeschel Verlag, 2007: 204-216.

BRANDL, Friedrich, Harrald GRILL und Bernhard SETZWEIN (Hrsg.). 2009. Zu Fuß auf der Goldenen Straße. Eine literarische Wanderung von Pilsen nach Amberg. München: Verlag Sankt Michaelsbund, 2009.

DUBOVÁ, Jindra. 2019. Bernhard Setzwein: Na počátku mého zájmu o Českou republiku stála literatura [Bernhard Setzwein: Literature Lies at the Root of My Interst in the Czech Republic]. Literárni noviny (2019): 1: 3.

ECKER, Hans-Peter und Kirsta Viola ECKER (Hrsg.). 2015a. Bernhard Setzwein: HRABAL und der Mann am Fenster. Bamberg: University of Bamberg Press, 2015.

ECKER, Hans-Peter und Kirsta Viola ECKER. 2015b. Kommentar. In Hans-Peter Ecker und Kirsta Viola Ecker (Hrsg.). Bernhard Setzwein: HRABAL und der Mann am Fenster. Bamberg: University of Bamberg Press, 2015: 87-125.

ECKER, Hans-Peter a Kirsta Viola ECKER. 2015c. Nachwort. In Hans-Peter Ecker und Kirsta Viola Ecker (Hrsg.). Bernhard Setzwein: HRABAL und der Mann am Fenster. Bamberg: University of Bamberg Press, 2015: 127-136.

HRABAL, Bohumil. 1989. Kdo jsem [Who I am]. Praha: Pražská imaginace, 1989.

SETZWEIN, Bernhard. 1978. vareck. Feldafing/Obb: Friedl Brehm Verlag, 1978.

SETZWEIN, Bernhard. 1981. Brandwunden. Feldafing/Obb: Friedl Brehm Verlag, 1981.

SETZWEIN, Bernhard. 1993a. An den Ufern der Isar. Ein bayerischer Fluß und seine Geschichte. München/Berlin: Koehler und Amelang, 1993.

SETZWEIN, Bernhard. 1993b. OberländerEckeDaiser. Gedicht. München: A 1 Verlag, 1993.

SETZWEIN, Bernhard. 1997. Zucker. Ein Stück. Diabetische Farce in 4 Szenen. Viechtach: lichtung verlag, 1997.

SETZWEIN, Bernhard. 1999. Das Buch der sieben Gerechten. Innsbruck: Haymon-Verlag, 1999.

SETZWEIN, Bernhard. 2001. Ein Fahneneid aufs Niemandsland. Literatur über Grenzen. Essays, Reden, Interviews. Viechtach: lichtung verlag, 2001.

SETZWEIN, Bernhard. 2003. Die grüne Jungfer. Innsbruck: Haymon Verlag, 2003.

SETZWEIN, Bernhard. 2007a. Ein seltsames Land. Viechtach: lichtung verlag, 2007.

SETZWEIN, Bernhard. 2007b. Zelená panna (román ze středu Evropy) [Die Grüne Jungfer]. Překl. Lenka Šedová. Brno: Barrister\&Principal, 2007.

SETZWEIN, Bernhard. 2009. Wo bleibt das Spalier fähnchenschwingender Schulkinder? In Friedrich Brandl, Harald Grill und Bernhard Setzwein (Hrsg.). Zu Fuß auf der Goldenen Stra$\beta$ e. Eine literarische Wanderung von Pilsen nach Amberg. München: Verlag Sankt Michaelsbund, 2009: 15-20.

SETZWEIN, Bernhard. 2012. Der neue Ton. Viechtach: lichtung verlag, 2012.

SETZWEIN, Bernhard. 2015a. „Herr Schriftsteller, vergessen Sie die Mütze nicht!“ Mitteleuropa und der gar nicht kalte Osten (Bamberger Poetikvorlesung, 2004). In Hans-Peter Ecker und Kirsta Viola Ecker (Hrsg.). Bernhard Setzwein: HRABAL und der Mann am Fenster. Bamberg: University of Bamberg Press, 2015: 145-231. 
SETZWEIN, Bernhard. 2015b. HRABAL und der Mann am Fenster. In Hans-Peter Ecker und Kirsta Viola Ecker (Hrsg.). Bernhard Setzwein: HRABAL und der Mann am Fenster. Bamberg: University of Bamberg Press, 2015: 9-85.

SETZWEIN, Bernhard. 2017. Der böhmische Samurai. Innsbruck: Haymon Verlag, 2017.

SETZWEIN, Bernhard. 2021. Osobní korespondence s autorkou. [Personal correspondence with the author] (10. 3. 2021).

SETZWEIN, Bernhard. n.d. Hrabal a muž u okna [Hrabal und der Mann am Fenster]. Berlin: Gallissas, n.d. 


\section{Mgr. Jindra Dubová, Ph.D.}

Univerzita Hradec Králové

Pedagogická fakulta

Rokitanského 62, 50003 Hradec Králové, Česká republika

jindra.dubova@uhk.cz

Jindra Dubová působí na Katedře německého jazyka a literatury na Pedagogické fakultě Univerzity Hradec Králové $\vee$ oboru literatura. Vystudovala německý jazyk a výtvarnou výchovu pro SŠ na Pedagogické fakultě Západočeské univerzity v Plzni. Studium zakončila diplomovou prací na téma "Deutsche und tschechische Melusine". V roce 2014 obhájila disertační práci "Bernhard Setzwein und der tschechische Aspekt in seinem Schaffen" na Univerzitě Palackého v Olomouci. Jejím výzkumným záměrem jsou české elementy $\vee$ bavorské literatuře.

Jindra Dubová works at the Department of German Language and Literature, University of Hradec Králové. She studied German and Visual Arts Education at the University of West Bohemia, where she defended her MA thesis 'Deutsche und tschechische Melusine'. In 2014, she finished her PhD studies at the Palacký University Olomouc with a thesis entitled 'Bernhard Setzwein und der tschechische Aspekt in seinem Schaffen'. Her research interests are Czech features in Bavarian literature. 